\title{
Management Development Programs and the Aspired Management Style: A Study in Malaysia
}

\author{
DOI: 510.12776/QIP.V19I2.607 \\ Nurita Juhdi, Wan Jamaliah Wan Jusoh, Norizah Supar, \\ Noor Hasni Juhdi
}

Received September 09 2015, Accepted 10 October 2015, Published 31 December 2015

\begin{abstract}
Purpose: The study was to examine the relationship between management development programs and the management styles used by junior executives and young managers.
\end{abstract}

Design/methodology/approach: Data was collected using survey forms and all the respondents were below 45 years old. They were either professionals or holding middle to higher level positions.

Findings: Only mentoring had significant relationships with all the seven management styles. Mentoring was also found as the only program which was significant predictor to all the management styles. Assessment programs were found having significant relationship with participative style with negative relationship. On-the-job development programs were only significantly related to two management styles. Delegating style was significantly related to all the management development programs. Ethical management style was only significant to mentoring.

Research implications: HR practitioners should emphasize the use of mentoring with systematic mentoring programs.

Research limitations: The correlation values among variables were weak-tomoderate and some variables suffered from low Cronbach's alpha values.

Originality/value: The paper researched on the outcomes of management development programs by measuring the management styles as perceived by the program participants.

Category: Research paper

Keywords: assessment; management styles; Malaysia; mentoring; on-the-job development programs; off-the-job development programs 


\section{INTRODUCTION}

Most development programs implemented in organizations are off-the-job programs such as courses, seminars, workshops, assessment and mentoring (London and Mone, 1999; Noe, et al., 1997). However, there are also on-the-job programs which give the opportunity to the junior executives and potential managers to learn by doing like special projects. According to McCall, Lombardo and Morrison (1988), on-the-job experience is more effective in equipping the employees with the skills and knowledge to become a good manager. But they also cautioned that on-the-job experience will only be effective if the program is designed in such a way that is challenging and stimulating the mind of the employees. As posited earlier by McCall et al. (1988), management development programs can vary in terms of the effectiveness depending on the quality and intensity of the program. Huge investment in the programs would only be a big waste if the intended objectives are not achieved. High potential employees might be frustrated and the employers might lose the talents.

\section{REVIEW OF LITERATURE}

Off-the-job development programs

Common off-the-job development programs like work related courses, seminars and workshops can lead to higher productivity and better output (Mincer, 1991; Groot and Maasen van den Brink, 2000; Tome, 2007). Noe (2008) described that sometimes corporate organizations arrange some sort of formal education, training and seminar programs for their employees to gain new skills and knowledge relevant to their jobs. In those programs employees learn from consultants or corporate university teachers about their job related skills and knowledge. Some of the employees might not have these basics in their academic background and therefore, participating in formal trainings like this would widen their understanding on the dynamic environment of the business.

Development programs which are conducted using off-the-job method can be costly. According to Frost and Wallingford (2013), the cost include paying the training staff, buying training materials, training fees, transportation, accommodation and food as well as the lost productivity due to absence of the staff attending training. Another major concern about the method is the far knowledge transfer - i.e. weak link between what is learned during the training program and what is practiced at the workplace.

\section{On-the-Job development programs}

On-the-job experience is part of management development program and it increases the skills of employees and molds the constructive managerial style. These programs give employees new work experience and make them capable of doing unfamiliar things. It is mentioned by Snell (1990) and Van der Heijden (2002) that if employees get experience by working in different positions, they 
will be able to perform multiple tasks. It will build self-confidence on the job. This is further supported by Juhdi et al. (2010) who conducted a research on identifying factors that influence employability in the organization. They also have the tendency to be entrusted with new projects and job assignments.

Nonetheless, there were studies which revealed that such programs are only effective if certain conditions are present. It was found that executives and potential managers who had the opportunity doing challenging work assignments and performing heavy responsibilities reported acquiring more developmental skills than those who only got to experience routine and less challenging tasks (McCall and Hollenbeck, 2002). Further, McCauley et al., (1994) postulated that a well-planned on-the-job development programs should have a number of characteristics which allow the employees to perform unfamiliar responsibilities, create and manage change, have high level of responsibility (dealing with deadlines, pressures) and deal with others at work.

\section{Mentoring}

Murray (1991) defines mentoring as a process where an employee learns from his or her manager or high skilled employees and tries to be skillful in the workplace. Lueneburger (2012) found that the role of coaches in developing talents is highly significant in determining the effectiveness of talent management. Dreher and Ash (1990) revealed that employees who received extensive mentoring relationships reported getting more job promotions, had higher incomes and were more satisfied.

Bandura (1977) and Decker and Nathan (1985) noted that employees tend to learn and pick up prominent managerial skills and practices by observing the behaviour of effective senior managers. However, Marsh (1992) and Walker (2002) noted that there were managers who served as mentors and coaches but they are reluctant to confront the mentees and be honest in giving the feedbacks. Other factors which influence mentoring quality in management development also include the time constraints due to high workload, cancellation of meetings with mentors due to unforeseen circumstances and poor quality of advices given by mentors (Jones, 2012).

\section{Assessment programs}

The common assessment programs are like assessment centres, performance appraisals, 360 degree feedback system and conducting psychological tests to assess skills, personality and decision making style (Noe, 2008).

DeRue and Wellman (2009) found that those who received more feedback on their performance tend to have stronger relationship between the development programs and their managerial skills. This view is supported by others (Halpern, 2004; Morrison and Brantner, 1992) who concurred that assessment programs are very pertinent in the development of managers.

Nevertheless, Edwards (2012) cited a survey conducted among HR practitioners and discovered that only 8 percent of the participating organizations reported 
using truly systematic methods to assess their high potential employees. Similar observation was also found by Juhdi, Pa'Wan and Hansaram (2013) in their survey on 237 employers in Malaysia which revealed that systematic talent assessment and evaluation was rated as quite uncommon in identifying employees' professional and managerial talents.

\section{Management styles and practices}

Likert (1967) categorized four styles of management; exploitative, paternalistic, consultative and participative management styles. Likert's work on management styles indicated that managers are still responsible to monitor, control and observe the subordinates in varying extent according to the context and depending on the employees' work motivation. Harbison and Myers (1969) also proposed almost the same styles but they introduced the laissez-faire style.

Mintzberg (1973) later posited that managers are not just to serve the role of managing the organization and performing the administrative duties but they should be entrepreneurial and behaving like the persons who own the organization. His view has added a big shift in managers' style in running organizations because they are no longer perceived as just another boss, but they are also expected to identify opportunities to expand the business. Over time, the managers' responsibilities are evolving from performing basic administrative functions to being entrepreneurial. The changes in the internal and external environment of organizations have impacted substantially on the managers' style. Khandwalla (1995) articulated a number of management practices dimensions which also include altruism. Altruism is a motivational state with the ultimate goal of increasing another's well-being (Batson, 1991). This is where the need to consider "the others" is emphasized. The term "others" refers to the people within the same unit like superiors, co-workers, subordinates as well as those who are outside the unit.

\section{CONCEPTUAL MODEL AND HYPOTHESES}

The present study uses the premises of social learning theory by Bandura (1977) which acknowledges that human beings learn mostly from observing the behaviours around them which serve as models. From observation and socialization, humans learn how to behave, think and act. Social learning theory posits that humans learn by paying attention to someone or a behaviour which is unique, distinct and valuable. Then they will start to retain the memory in their mind and will start reproducing the behaviour by mimicking or emulating the actions of the "models" which they have observed. Finally, the motivation of the humans to repeat the same behaviours and action tends to increase depending on the reinforcement given such as encouragement, rewards, incentives or punishments.

According to Decker (2007), the social learning theory is applicable in training and management development programs because it can be used in introducing 
new behaviours and attitude. The learning theory has been widely used in management learning research as a process of learning by organizations for problem solving and decision making, entrepreneurial opportunity seeking and strategy formulation.

Using the premises of social learning theory, we hypothesize that management development programs as expounded earlier are able to produce the expected managerial competencies. Junior executives and lower level managers who undergo various programs learn by observing the behaviours of others and are expected to exhibit the expected behaviour and attitude in performing their duties at work. As for assessment programs, as posited earlier by many scholars (for e.g. DeRue and Wellman, 2009; Halpern, 2004; Morrison and Brantner, 1992), the programs are not a form of teaching or training for employees to learn but such programs are regarded as a crucial factor which must be present in management development programs. Therefore, the following hypotheses were forwarded:

H0: Management development programs are not related to management practices

H1: Management development programs are significantly related to management practices

The above hypotheses were forwarded because the study aimed to examine which of the four management development programs were significantly related to the seven management practices. Thus, bivariate correlation tests were employed to examine the correlations between two variables.

Another hypothesis forwarded was to examine the relationship between the whole set of predictors (i.e. the four management development programs) and the dependent variables (i.e. management practices):

H2: Management practices can be predicted by management development programs

The objective was to determine which of the four management development programs could best predict each of the seven management practices. Therefore, a multiple linear regression were used (this is the extension of bivariate correlation) and the result of regression would indicate the best prediction of each of the seven management practices.

\section{METHODOLOGY}

\section{Participants}

Data were collected using survey forms that contained items that measured studied variables. Given the objective of the study, the respondents must meet a number of criteria. The employees must be below 45 years old, professionals or holding middle to higher level positions (lowest position was junior executive). This was because these were the people who had the potential to assume higher 
positions in the organizations. They must had gone through some extent of management development programs. One thousand survey forms were distributed to employees who met with the criteria set by the researchers and a total of 413 forms were received but quite a number of forms were poorly responded and thus only 399 were used for further analysis.

\section{Demographics}

Based on the data collected, the male employees made up 58 percent of the total respondents and the majority (i.e. 60 percent) was those aged between 31 to 45 years old. The rest (i.e. 40 percent) were below 30 years of age. In terms of ranks in the organization, 28 percent were junior executives, 38 percent in low level managerial post and 20 percent in middle level post. Fourteen percent were professionals who were in middle to high ranks in organizations.

\section{Measures}

The survey form was divided into two sections. Section A contained 22 items that measured four approaches in management development programs; "off-thejob development programs", "on-the-job development programs", "assessment programs" and "mentoring". The first three development programs were measured using items which were adopted and adapted from Juhdi, Pa'Wan and Hansaram (2013) and mentoring was measured using items from Dreher and Ash (1990). All the items in this section were measured on a Likert scale of 1 (never) to 5 (very often). Items in Section B measured "management style and practices" which used items adopted and adapted from Culpan and Kucukemuroglu (1993), Selvarajah and Meyer (2008) and Khaliq and Ogunsola (2011). All the items were measured on a 5-point scale, which ranged from 1 (Strongly Disagree) to 5 (Strongly Agree).

\section{Reliability of measurement items}

Factor analysis on items in Section A (management development programs) produced 5 factors consisting of items for the respective variables which explained 56.8 percent of the total variance. Factor 1 contained 6 items on "assessment programs" with Cronbach's alpha .823 (sample items: psychological tests (e.g. personality tests and attitude tests), assessment centers (using a number of exercises such as role plays, business games and leaderless group discussions), and performance appraisal by subordinates). Factor 2 has all the 5 items on "mentoring" loaded in the intended group with Cronbach's alpha .748. The sample items were I have been introduced to people who can increase my contact with important individuals in the organization, my mentor is willing to listen to my concerns and feelings I have about my job; and I have been introduced to people at work who are prepared to help me develop my managerial skill. There were 4 items in factor 3 that reflected "on-the-job development programs" with Cronbach's alpha .708. The sample items were assigned to work on special projects, switch roles with co-workers; and opportunity to take temporary roles at another company on full time basis. In factor 4, all the four items were loaded clear cut reflecting "off-the-job 
development programs". The sample items were attend seminars and conferences, participate in management development courses; and participate in workshops. However, one item had to be removed (i.e. do my degree program for e.g. Diploma, Bachelor and Master) in order to increase the Cronbach's alpha to .740. The last factor was dropped due to its nature which was not interpretable.

The second factor analysis on management style and practices in Section B produced 7 factors that consisted of items for the respective variables which explained 55.04 percent of the total variance. Table 1 show the full result from the factor analysis.

Table 1 - Statistics and principal component loadings of Management Style and Practices measures

\begin{tabular}{lcc}
\hline Factor & $\begin{array}{c}\text { Factor } \\
\text { loadings }\end{array}$ & $\begin{array}{c}\text { Cronbach's } \\
\text { alpha }\end{array}$ \\
\hline Factor 1: Altruistic & .720 & .788 \\
Bargain with other units & .640 & \\
Provide assistance to other units for favors & .627 & \\
Make deals with other units & .506 & \\
Coordinate with other units & .472 & \\
Consider employees' personal matters & .421 & \\
Help employees with non-work related matters & .405 & \\
Care for subordinates' overall wellbeing & & \\
\hline
\end{tabular}

Factor 2: Goal clarity

Emphasize on meeting department/unit goals $\quad .706$

Communicate changes of policies and directives to .667

employees

Communicate to employees their work goals $\quad 655$

Follow up and check employees' work progress $\quad .519$

Convey employees' feedbacks to top management $\quad .475$

Factor 3: Participative

.779

Give employees freedom to select their own course of $\quad .773$

actions

Allow free flow of information $\quad .704$

Allow employee participation in decision making $\quad .582$

Get myself informed about things happening within unit $\quad .487$

Give freedom to employees to schedule their own work $\quad .465$

Factor 4: Innovative

Try different approaches to management $\quad .646$

Accept unpopular projects $\quad .608$

Tackle unusual work problems $\quad .575$

Use consensus decision making $\quad .569$

Try innovative methods in people management $\quad .454$ 


\begin{tabular}{|c|c|c|}
\hline Factor & $\begin{array}{c}\text { Factor } \\
\text { loadings }\end{array}$ & $\begin{array}{l}\text { Cronbach's } \\
\text { alpha }\end{array}$ \\
\hline Factor 5: Realistic & & .671 \\
\hline Act based on what is practical than ideal & .682 & \\
\hline Behave in accordance with my religious belief & .662 & \\
\hline Be responsive to realities in the environment & .563 & \\
\hline Make decisions based on organizational demand & .451 & \\
\hline Initiate improvements & .379 & \\
\hline Factor 6: Delegating & & .658 \\
\hline Give discretion to my subordinates & .693 & \\
\hline Solicit for workers' inputs and suggestions & .677 & \\
\hline Delegate authority to employees & .663 & \\
\hline Be democratic & .506 & \\
\hline Factor 7: Ethical & & .616 \\
\hline $\begin{array}{l}\text { Follow what is morally right }- \text { not what is right for me or } \\
\text { organization }\end{array}$ & .703 & \\
\hline $\begin{array}{l}\text { Decide based on morality when it conflicts with } \\
\text { organizational goal }\end{array}$ & .479 & \\
\hline
\end{tabular}

\section{RESULTS}

Table 2 presents the means, standard deviations, and intercorrelations of the studied variables. The significant correlations (i.e. $r$ values) that ranged from .10 to .32 indicated weak-to moderate relationships between the seven types of management style and the four management development programs.

H1 states that management development programs are significantly related to management style and practices. The findings indicated that only mentoring had significant relationships with all the measures of management styles - altruistic ( $\mathrm{r}$ $=.317, \mathrm{p}=.000)$, goal clarity $(\mathrm{r}=.273, \mathrm{p}=.000)$, participative $(\mathrm{r}=.202, \mathrm{p}=$ $.000)$, innovative $(\mathrm{r}=.168, \mathrm{p}=.001)$, realistic $(\mathrm{r}=.272, \mathrm{p}=.000)$, ethical $(\mathrm{r}=$ $.201, \mathrm{p}=.000)$ and delegating $(\mathrm{r}=.223, \mathrm{p}=.000)$.

As for formal education, it also had significant relationships with all the management styles, except for ethical management style $(r=.029, \mathrm{p}=.566)$. Assessment program were found having significant relationship with participative style $(\mathrm{r}=-.116, \mathrm{p}=.021)$ with negative relationship. Another unexpected finding is when on-the-job development programs were only significantly related to two managerial styles - altruistic $(r=.162, p=.001)$ and delegating styles $(\mathrm{r}=.191, \mathrm{p}=.000)$. 
Table 2 - Means, standard deviations, and intercorrelations of the study variables $(N=399)$

\begin{tabular}{|c|c|c|c|c|}
\hline & $\begin{array}{l}\text { Assessment } \\
\text { programs }\end{array}$ & Mentoring & $\begin{array}{l}\text { On-the-job } \\
\text { development } \\
\text { programs }\end{array}$ & $\begin{array}{l}\text { Off-the-job } \\
\text { development } \\
\text { programs }\end{array}$ \\
\hline & $\begin{array}{l}(\mathrm{M}=2.9, \\
\mathrm{SD}=.67)\end{array}$ & $(\mathrm{M}=3.3, \mathrm{SD}=.59)$ & $(\mathrm{M}=3.1, \mathrm{SD}=.69)$ & $\begin{array}{l}(\mathrm{M}=3.2, \\
\mathrm{SD}=.74) \\
\end{array}$ \\
\hline $\begin{array}{l}\text { Altruistic } \\
(\mathrm{M}=3.4, \mathrm{SD}=.48)\end{array}$ & .05 & $.32 * *$ & $.16^{* *}$ & $.23 * *$ \\
\hline $\begin{array}{l}\text { Goal clarity } \\
(\mathrm{M}=3.5, \mathrm{SD}=.56)\end{array}$ & -.03 & $.27 * *$ & .09 & $.26^{* *}$ \\
\hline $\begin{array}{l}\text { Participative } \\
(\mathrm{M}=3.4, \mathrm{SD}=.64)\end{array}$ & $-.12 *$ & $.20 * *$ & .05 & $.19 * *$ \\
\hline $\begin{array}{l}\text { Innovative } \\
(\mathrm{M}=3.5, \mathrm{SD}=.54)\end{array}$ & -.01 & $.17^{* *}$ & .03 & $.11^{*}$ \\
\hline $\begin{array}{l}\text { Realistic } \\
(\mathrm{M}=3.7, \mathrm{SD}=.52)\end{array}$ & $.10^{*}$ & $.27 * *$ & .05 & $.17 * *$ \\
\hline $\begin{array}{l}\text { Ethical } \\
(\mathrm{M}=3.7, \mathrm{SD}=.59)\end{array}$ & .04 & $.20 *$ & .07 & .03 \\
\hline $\begin{array}{l}\text { Delegating } \\
(\mathrm{M}=3.6, \mathrm{SD}=.51)\end{array}$ & $.14 * *$ & $.22 * *$ & $.19^{* *}$ & $.23 * *$ \\
\hline
\end{tabular}

Delegating style that was significantly related to all the management development programs - assessment programs $(\mathrm{r}=.135, \mathrm{p}=.007)$, mentoring $(\mathrm{r}$ $=.223, \mathrm{p}=.000)$, on-the-job development programs $(\mathrm{r}=.191, \mathrm{p}=.000)$ and offthe-job development programs $(\mathrm{r}=.228, \mathrm{p}=.000)$. Ethical management style was only significant to mentoring $(\mathrm{r}=.201, \mathrm{p}=.000)$. As for the other seven types of managerial styles and practices, they were significantly related to at least two management development programs. The mixed results found from the Pearson's correlation test between the management development programs and the management styles indicated that $\mathrm{H} 1$ is partially supported (and $\mathrm{H} 0$ is not supported at all).

$\mathrm{H} 2$ stated that management styles and practices can be predicted by management development programs. To test the hypothesis, multiple linear regressions were conducted and Table 3 shows the results.

The results show that the $\mathrm{R}^{2}$ produced from the seven multiple linear regressions (MLR) ranged from .330 to .081. Altruistic management style was significantly predicted by mentoring $(\beta=.287, p=.000)$ and off-the-job development programs $(\beta=.130, p=.014)$; goal clarity was significantly predicted by three management development programs - assessment programs $(\beta=-.156, \mathrm{p}=$ $.005)$, mentoring $(\beta=.261, \mathrm{p}=.000)$, off-the-job development programs $(\beta=$ $.205, \mathrm{p}=.000)$; participative style was significantly predicted by assessment $(\beta$ $=-.236, p=.000)$, mentoring $(\beta=.224, p=.000)$, off-the-job development programs $(\beta=.154, \mathrm{p}=.004)$; innovative style was significantly predicted by 
mentoring $(\beta=.190, \mathrm{p}=.001)$; realistic style was significantly predicted by mentoring $(\beta=.280, \mathrm{p}=.000)$ and on-the-job development programs $(\beta=.126$, $\mathrm{p}=.037)$; ethical style was significantly predicted by mentoring $(\beta=.236, \mathrm{p}=$ $.000)$; and finally delegating style was significantly predicted by mentoring $(\beta=$ $.124, \mathrm{p}=.032)$ and off-the-job development programs $(\beta=.148, \mathrm{p}=.007)$. Therefore, $\mathrm{H} 2$ is partially supported.

Table 3 - Summary of multiple linear regression for variables predicting managerial styles and practices as the dependent variables $(N=399)$

\begin{tabular}{|c|c|c|c|c|c|c|c|}
\hline & $\begin{array}{c}\text { Altruistic } \\
\beta\end{array}$ & $\begin{array}{c}\text { Goal } \\
\text { clarity } \\
\beta\end{array}$ & $\begin{array}{c}\text { Participative } \\
\beta\end{array}$ & $\begin{array}{c}\text { Innovative } \\
\beta\end{array}$ & $\begin{array}{c}\text { Realistic } \\
\beta\end{array}$ & $\begin{array}{c}\text { Ethical } \\
\beta\end{array}$ & $\begin{array}{c}\text { Delegating } \\
\beta\end{array}$ \\
\hline \multirow[t]{2}{*}{$\mathrm{AP}$} & -.107 & -.156 & -.236 & -.074 & .037 & -.029 & .021 \\
\hline & $(.054)$ & $(.005)$ & $(.000)$ & (.199) & $(.513)$ & $(.613)$ & $(.717)$ \\
\hline \multirow[t]{2}{*}{ Mentoring } & .287 & .261 & .224 & .190 & 280 & .236 & .124 \\
\hline & $(.000)$ & $(.000)$ & $(.000)$ & $(.001)$ & $(.000)$ & $(.000)$ & $(.032)$ \\
\hline \multirow[t]{2}{*}{ NJDP } & .036 & -.031 & .005 & -.044 & .126 & -.003 & .070 \\
\hline & $(.541)$ & $(.601)$ & $(.932)$ & $(.478)$ & $(.037)$ & $(.965)$ & $(.246)$ \\
\hline \multirow[t]{2}{*}{ FJDP } & .130 & .205 & .154 & .062 & .091 & -.059 & .148 \\
\hline & $(.014)$ & $(.000)$ & (.004) & $(.265)$ & $(.092)$ & $(.289)$ & $(.007)$ \\
\hline $\mathrm{R}^{2}$ & .330 & .300 & .295 & .081 & .218 & .106 & .220 \\
\hline
\end{tabular}

Notes: figures in parentheses are the p-values. AP: Assessment programs, NJDP: On-the-job development programs, FJDP: off-the-job development programs

\section{DISCUSSION OF THE FINDINGS}

The study revealed that mentoring was the sole program which was significantly related to all the management practices (refer to Table 2), and mentoring was the only program which was significant predictor to all the seven management styles and practices (refer to Table 3). At this juncture, we can suggest that mentoring must be given the emphasis in building managerial talent. As posited by many scholars (Catalyst, 1993; Noe, Greenberger and Wang, 2002; Godshalk and Sosik, 2003; Allen et al. 2004), mentoring is very effective in building talents and skills which are imperative to fulfil personal and organizational needs. To foster managerial attitude which encompasses a wide spectrum from being goaloriented to altruistic to morality, guidance from more experienced figures is very important. It is crucial to design mentoring program systematically which is aligned with the organizational strategies.

Off-the-job development program is another management program which was found having significant relationships with most of the management styles and practices (except for ethical style) (refer to Table 2). The significant relationships suggest that the more such programs are used, the more the managers exhibit the expected management styles and practices. However, the tertiary education is quite expensive, time consuming and the courses might not be relevant to the 
organization. Thus, other off-the-job programs are available like seminars, workshops and courses which are shorter in duration and the skills/knowledge learned are more applicable to the needs of the employers.

Nonetheless, the insignificant relationship between off-the-job development program and ethical management style is quite disturbing but plausible. An individual may not learn effectively about morality via formal learning setting. During formal education programs, they may be exposed to philosophies and theories in moral, ethics and values but to foster moral values in an individuals, possibly the more effective approach is through socialization especially with mentors and senior personnel. This is also indicated in the study findings which showed ethical style was only significantly related to mentoring (refer to Table 2) and mentoring being the sole significant predictor for ethical style (refer to Table $3)$.

On-the-job development program was found only significantly related to altruistic and delegating management styles. It is quite surprising because numerous studies indicated the importance of on-the-job development program as one of the approaches to equip potential employees with business management skills and knowledge (Noe, 2008; Peters and Smith, 1996; Lombardo and Eichinger, 2000). Furthermore, such program is the most common way used by organizations due to its realistic nature as compared to formal education. Lombardo and Eichinger (2000) even posited that every management development program must have the 70 percent hands-on, 20 percent mentoring and 10 percent formal education. In Table 3, it is shown that on-the-job development program was insignificant predictor for most of all the management styles but only significant to one, i.e. realistic style. This finding further adds to the credibility of such programs. One possible explanation here maybe lies in the argument made by many authors as expounded earlier (for e.g. McCall and Hollenbeck, 2002; McCall, Lombardo and Morrison, 1988; Cox and Cooper, 1988) which posited the importance of giving challenging and unfamiliar tasks in on-the-job experience. The second plausible explanation could be the fact that the respondents are at the low and middle level management who have yet to be exposed to the crux and core of the organization problems. As postulated by McCauley et al., (1994), on-the-job development programs which are not systematic and weak in implementation would render the program to be ineffective.

Assessment programs were found as insignificant predictors for most of the management styles (refer to Table 3) and the programs were also insignificantly related to four management styles and practices (namely altruistic, goal-oriented, innovative and ethical styles). On one angle, the findings as if suggested that assessment programs are almost irrelevant in management development but the major reason being is due to the nature of assessment (that comprised of performance appraisals and assessment centers) which was more appropriate for identifying talents and potentials of employees, rather than equipping them with the managerial skills. As recommended by DeRue and Wellman (2009), 
managers must be given feedback on how well or bad they perform because they need to know the areas for improvement.

\section{IMPLICATIONS OF THE STUDY}

The study findings provided strong support to the social learning theory. The findings indicated that young managers and junior executives learn management styles and practices mainly by mentoring programs and off-the-job development programs. As posited by the theory, the learners acquire new skills, knowledge and abilities from observation and socialization. However, the lack of significant contribution of on-the-job behaviour on management styles and practices require further investigation.

Given the striking results which indicate mentoring as the "super star" of all the management development programs, thus HR practitioners should emphasize the use of mentoring. As posited by Groves (2007), the success of mentoring relationship hinges upon the management of the program and quality of the relationship. Hence, mentoring program should start with careful selection of mentors who are matched with the right protégés.

\section{LIMITATIONS OF THE STUDY}

The present study had several limitations. First, despite the significant relationships found in the Pearson's correlation tests, the $r$ values ranged from .10 and .32 which indicate weak-to-moderate relationships between the management programs and the aspired management styles. Second, the four dimensions of aspired management style (namely innovative, realistic, delegating and ethical) suffered from low Cronbach's alpha values (below 0.7 as recommended by Nunnally, 1978) and thus low reliability. Therefore, interpretations which involve the relevant dimensions have to be made with caution. Third, the $\mathrm{R}^{2}$ obtained from the MLR (refer to Table 3) was between .081 and .330 which indicated low-to-moderate explanatory power of the management development programs in explaining the variance of the management styles and practices. Thus, there are other factors which could better explain the variances which are more powerful that must be further investigated and researched.

\section{ACKNOWLEDGMENTS}

The research was fully funded by Research Acculturation Grant Scheme 2013/14 (RAGS) under the Ministry of Higher Education Malaysia. 


\section{REFERENCES}

Allen, T.D., Eby, L., Poteet, M., Lentz, E. and Lima, L., 2004. Career benefits associated with mentoring for protégés: A meta-analysis. Journal of Applied Psychology, 89(1), pp.127-136.

Bandura, A., 1977. Social Learning Theory. Englewood Cliffs, NJ: Prentice Hall.

Batson, C.D., 1991. The altruism question: Toward a social-psychological answer. Hillsdale, NJ: Erlbaum Associates.

Catalyst, C., 1993. Mentoring: A guide to corporate programs and practices. New York: Catalyst.

Cox, C.J. and Cooper, C.L., 1988. High flyers: An anatomy of managerial success. New York: Blakwell.

Culpan, R. and Kucukemuroglu, O., 1993. A Comparison of U.S. and Japanese management styles and unit effectiveness. Management International Review, 33(1), pp.27-42.

Decker, P., 2007. Social Learning Theory and Leadership. Journal of Management Development, 5(3), pp.46-58.

Decker, P.J. and Nathan, B.R., 1985. Behavior modeling training. New York: Praeger.

DeRue, D.S. and Wellman, N., 2009. Developing leaders via experience: The role of developmental challenge. Journal of Applied Psychology, 94(4), pp.859875.

Dreher, G.F. and Ash, R.A., 1990. A comparative study of mentoring among men and women in managerial, professional, and technical positions. Journal of Applied Psychology, 75(5), pp.539-546.

Edwards, S., 2012. Maintaining the delicate balance when developing highpotential programs. $T \& D, 66(4)$, pp.60-65.

Frost, D.E. and Wallingford, V., 2013. Experiential learning for developing managers: a practical model. Journal of Management Development, 32(7), pp.756-767.

Godshalk, V.M. and Sosik, J.J., 2003. Aiming for career success: the role of learning goal orientation in mentoring relationships. Journal of Vocational Behavior, 63(3), pp.417-437.

Groot W. and Maasen van den Brink, H., 2000. Education, training and employability. Applied Economics Journal, 32(5), pp.573-581.

Groves, K.S., 2007. Integrating leadership development and succession planning best practices. Journal of Management Development, 26(3), pp.239- 260.

Halpern, D.F., 2004. The development of adult cognition: Understanding constancy and change in adult learning. In D.A. Day, S.J. Zaccaro, and S.M. 
Halpin, eds. Leader developmen for transforming organizations, Mahwah. NJ: Erlbaum. pp.125-152.

Harbison, F. and Myers, C.A., 1969. Management in the industrial world: an international analysis. In UJF, Ewurum, ed. Management and Organizational Performance in Igbo Cultural Perspective, Enugu: University of Nigeria.

Jones, J., 2012. An Analysis of Learning Outcomes within Formal Mentoring Relationships. International Journal of Evidence Based Coaching and Mentoring, 10(1), pp.57-72.

Juhdi, N., Pa'Wan and F. Hansaram, R., 2013. Managing high potential employees: a case of employers in Malaysia. 3rd Asia-Pacific Business Research Conference, Kuala Lumpur, February.

Juhdi, N., Pa'Wan, F., Mokhsin, H. and Othman, N.A., 2010. Factors influencing internal and external employability of employees. Business and Economics Journal, 2010(11), pp.1-10.

Khaliq, A. and Ogunsola, O.K., 2011. An empirical assessment of Islamic leadership principles. International Journal of Commerce and Management, 21(3), pp.291-318.

Khandwalla, P., 1995. Effectiveness management styles: an Indian study. Journal of Euro Asian management, 1(1), pp.39-64.

Likert, R., 1967. The human organization. New York: McGraw - Hill Inc.

Lombardo, M. and Eichinger R., 2000. The leadership machine, Minnesota: Lominger International.

London, M. and Mone, E.M., 1999. Continuous learning. In D.R. Ilgen and E.D. Pulakos, eds. The changing nature of performance: Implicationsfor staffing, motivation, and development. San Francisco: Jossey- Bass. pp.119-153.

Lueneburger, A.E., 2012. Retaining high potential talent: assessment and coaching as a means of avoiding the "Mahna-Mahna" effect. International Journal of Evidence Based Coaching and Mentoring, 10(1), pp.125-131.

Marsh, L., 1992. Good manager: good coach? What is needed for effective coaching? Industrial and Commercial Training, 24(9), pp.3-8.

McCall, M.W. and Hollenbeck, G.P., 2002. Developing global executives: The lessons of international experience. Boston: Harvard Business School Press.

McCall, M.W., Lombardo, M.M. and Morrison, A.M., 1988. The lessons of experience: How successful executives develop on the job. Lexington: Lexington Books.

McCauley, C.D., Ruderman, M.N., Ohlott, P.J. and Morrow, J.E., 1994. Assessing the developmental components of managerial jobs. Journal of Applied Psychology, 79(4), pp.544-560. 
Mincer J., 1991. Education and employment. Massachusetts: National Bureau of Economic Research.

Mintzberg, H., 1973. Strategies making in three modes. California Management Review, 3(16), pp.44-53.

Morrison, R.F. and Brantner, T.M., 1992. What enhances or inhibits learning a new job: A basic career issue. Journal of Applied Psychology, 77(6), pp.926-940.

Murray M., 1991. Beyond the myths and the magic of mentoring: how to facilitate an effective mentoring program. CA: Josey-Bass Inc.

Noe R.A., 2008. Employee training and development. New York: McGraw-Hill.

Noe, R.A., Greenberger, D.B. and Wang, S., 2002. Mentoring: What we know and where we might go. In G.R. Ferris and J.J. Martocchio, eds. Research in personnel and human resources management, 21, pp.129-174.

Nunnally, J.C., 1978. Psychometric theory. New York: McGraw-Hill.

Peters, J. and Smith, P., 1996. Developing high-potential staff - an action learning approach. The Journal of Workplace Learning: Employee Counselling Today, 8(3), pp.6-11.

Selvarajah, C. and Meyer, D., 2008. One nation, three cultures: exploring dimensions that relate to leadership in Malaysia. Leadership and Organization Development Journal, 29(8), pp.693-712.

Snell R.S., 1990. Congenial ways of learning: so near yet so far. Journal of Management Development, 9(1), pp.17-23.

Tome, E., 2007. Employability, skills and raining in Portugal (1988-2000): Evidence from official data. Journal of European Industrial Training, 31(5), pp.336-357.

Van der Heijden B., 2002. Prerequisites to guarantee life-long employability. Personnel Review, 31(1), pp.44-61.

Walker, C.A., 2002. Saving your rookie managers from themselves. Harvard Business Review, 80(4), pp.97-102. 


\section{ABOUT AUTHORS}

Nurita Juhdi is an assistant professor at Kulliyyah of Economics and Management Sciences, International Islamic University Malaysia, e-mail: nurita@iium.edu.my

Wan Jamaliah Wan Jusoh is an associate professor at Kulliyyah of Economics and Management Sciences, International Islamic University Malaysia, e-mail: wjamaliah@iium.edu.my

Norizah Supar is an assistant professor at Kulliyyah of Economics and Management Sciences, International Islamic University Malaysia, e-mail: norizahs@iium.edu.my

Noor Hasni Juhdi is a senior lecturer at Faculty of Economics and Management, Universiti Kebangsaan Malaysia, e-mail: n_hasni@ukm.edu.my 